Gabriela Dobińska

Uniwersytet Łódzki

Karolina Walczak-Człapińska

Uniwersytet Łódzki

\title{
Metodologiczno-etyczne aspekty prowadzenia badań fokusowych $z$ udziałem przedstawicieli instytucjonalnego systemu wsparcia dla rodzin z problemem alkoholowym*
}

\section{Methodological and ethical aspects of conducting focus tests with representatives of the institutional support system for families with alcohol problems}

\begin{abstract}
Abstrakt
Celem artykułu jest refleksja nad dylematami o charakterze etyczno-metodologicznym, których doświadczyły badaczki w trakcie planowania oraz realizacji badań fokusowych z udziałem przedstawicieli instytucjonalnego systemu wsparcia dla rodzin z problemem alkoholowym.

W pierwszej części autorki przedstawiły główne założenia teoretyczne dotyczące realizacji badań fokusowych, wskazując na rozmaitość podejść, wątpliwości oraz dylematów wynikających m.in. ze statusu metodologicznego badania grupy fokusowej, elementów procedury badawczej, etyki, doboru uczestników, analizy zgromadzonego materiału empirycznego, roli moderatora, doboru przestrzeni oraz sposobu rejestracji badania.

Następnie w części metodologicznej badaczki zaprezentowały szczegółowy przebieg procedury badawczej, który stanowił swoisty wstęp dla trzeciej, ostatniej części analitycznej, w której autorki prezentują dylematy, a także sposoby radzenia sobie z ograniczeniami metodologicznymi, wskazując równocześnie na potencjał oraz możliwości badań fokusowych. Zrealizowany przez badaczki wywiad fokusowy z przedstawicielami instytucji pomocowych dla rodzin z problemem alkoholowym stanowił jedną z części szerszego projektu badawczego.
\end{abstract}

Słowa kluczowe: badania jakościowe, wywiad fokusowy, dylematy etyczne, problemy metodologiczne, badania społeczne

* Badania prowadzone przez zespół Pracowni Pedagogiki Specjalnej na Wydziale Nauk o Wychowaniu Uniwersytetu Łódzkiego w ramach projektu naukowego pt. „Rodzina w systemie wsparcia społecznego i pomocy osobom z problemem alkoholowym. Badania biograficzne z udziałem rodziców (dorosłych) dzieci uzależnionych od alkoholu”, realizowanego jako zadanie „Wspieranie badań naukowych w obszarze problemów wynikających z używania alkoholu" finansowane ze środków Narodowego Programu Zdrowia na lata 2016-2020. 


\section{Wprowadzenie}

Zogniskowany wywiad fokusowy często towarzyszy dyskusjom naukowym polskich badaczy, stanowi przedmiot rozważań socjologów, psychologów, pedagogów oraz przedstawicieli branży marketingowej. Analizując wybraną literaturę przedmiotu (zob. Lisek-Michalska, 2002, 2013; Drapikowska i Palczewska, 2013) okazuje się, że status metodologiczny wywiadu fokusowego przez wielu badaczy uznawany jest za nieuporządkowany i niejasny. Trudności ze wskazaniem podstaw epistemologicznych różnych zastosowań badania fokusowego oraz próba umiejscowienia ich wśród wiodących tradycji filozoficznych przyczynia się do powstawania odrębnych podejść w stosowaniu badań fokusowych. W zależności od reprezentowanej dyscypliny naukowej oraz sposobu rozumienia poznawania badanej rzeczywistości badacze różnie postrzegają badania fokusowe, utożsamiając je z cechami charakterystycznymi dla badań jakościowych lub ilościowych. Jolanta Lisek-Michalska $(2002,2013)$ zwraca uwagę na brak zgody wśród badaczy oraz pojawiające się wątpliwości co do paradygmatu metodologicznego, w obrębie którego można odnaleźć uzasadnienie teoretyczne dla metody zogniskowanego wywiadu grupowego. Pamela Kidd i Mark Parshall (2000) zwrócili uwagę, że grupy fokusowe rozwijały się często poza głównymi metodologicznymi tradycjami i założeniami badań jakościowych. Pomimo braku jasno określonych reguł dotyczących procedury badawczej cechy badań fokusowych są zbliżone do podejścia jakościowego.

Mając na uwadze powyższe, w badaniach Autorki wykorzystały metodę wywiadu fokusowego, a celem artykułu uczyniły trudności oraz dylematy towarzyszące realizacji badania z udziałem przedstawicieli instytucji pomocowych. Zaprezentowały także sposoby radzenia sobie z nimi w trakcie realizacji badań.

Wykorzystanie potencjału oraz możliwości badań fokusowych umożliwia analizę wygenerowanych danych w obrębie interakcjonizmu symbolicznego. Rzeczywistość w rozumieniu tego paradygmatu jest konstruowana w ramach ciągłych interakcji symbolicznych, gdzie role społeczne, a także statusy są konstruktami poddawanymi pewnym negocjacjom (por. Hałas, 2016; Konecki, 2000).

Świat w paradygmacie interpretatywnym ma charakter procesualny oraz emergentny, tworzony przez dynamikę wzajemnych interakcji aktorów społecznych mogących podejmować działanie, a w rezultacie nadawanie znaczeń (por. Hałas, 1994; Piotrowski, 1998; Konecki, 2000).

\section{Metodologiczne aspekty prowadzenia wywiadu fokusowego}

Pomimo obecnego w literaturze sporu badaczy na temat statusu metodologicznego badań fokusowych oraz prezentowaniu argumentacji mającej na celu identyfikację metody z badaniami jakościowymi badacz, planując zogniskowany wywiad fokusowy, musi mieć świadomość wagi podejmowanych decyzji w trakcie 
projektowania procedury badawczej. Przyjęcie określonych ustaleń metodologicznych ma swoje konsekwencje w planowaniu, zbieraniu, a następnie analizowaniu pozyskanego materiału empirycznego (zob. Lisek-Michalska, 2002, 2013; Barbour, 2011).

W literaturze zachodniej można odnaleźć wiele wyjaśnień terminologicznych dla wywiadu fokusowego. David Morgan (1997), definiując „fokus”, wskazuje na jego trzy główne elementy. Przede wszystkim podkreśla, że jest to metoda zorientowana na gromadzenie danych. Poza tym zwraca uwagę na interakcje zachodzące między uczestnikami dyskusji, a także podkreśla aktywną rolę badacza. Lia Litosseliti (2005) określa tę metodę jako nieformalną konwersację wybranych osób na konkretny, wskazany temat, który dotyczy sytuacji, przedmiotów, informacji lub wycinka rzeczywistości społecznej znanej wszystkim uczestnikom. Prezentowany przekrój kilku wybranych definicji zwraca uwage na wyłaniające się cechy wspólne, łączące różne podejścia. Przede wszystkim pozyskany materiał empiryczny pochodzi z dyskusji grupowej, w której każdy uczestnik może się swobodnie wypowiedzieć na określony temat, a interakcje zachodzące między rozmówcami stanowią podstawę wytworzonych danych oraz wskazują przebieg wywiadu.

Oprócz realizacji bardzo ważnym aspektem składającym się na całość procedury jest odpowiednie przygotowanie metodologiczne, organizacyjne oraz etyczne. W podjęciu trudu zaprojektowania badań fokusowych należy wziąć pod uwagę grupę - tj. uczestników. Dobór próby w tym przypadku z reguły opiera się na związku osób badanych z określonym przedmiotem badań (Babbie, 2013 , s. 345-346). Powołana grupa powinna mieć przynajmniej jedną wspólną cechę, zbyt duża jednowymiarowość i zbieżność mogłaby zakłócić proces generowania danych. Barbara Murphy (1992) uczula, że pojawiające się różnice zdań uczestników w obrębie określonego tematu mogą wznieść dyskusję na wyższy, bardziej przenikliwy poziom, umożliwiający wydobycie tego, co ukryte pod fasadą prezentowanych opinii. Liczba uczestników biorących udział w wywiadzie fokusowym w dużej mierze zależy od celu oraz przedmiotu dyskusji. W opracowaniach naukowych najczęściej wskazuje się 10-12 osób, aczkolwiek te wskazówki z reguły dotyczą badań marketingowych (zob. Babbie 2013; Barbour 2011). W badaniach społecznych bardziej atrakcyjne oraz ciekawsze jest dogłębne analizowanie znaczeń, interakcji, a także prezentowanych sposobów rozumienia tematu rozmowy przez uczestników. Mając na uwadze poruszenie drażliwego tematu oraz analizę wszystkich zaprezentowanych opinii oraz poglądów ze wskazaniem różnic, moderowanie dużych grup mogłoby być kłopotliwe i bardzo wymagające. Dlatego dopuszczalne jest prowadzenie wywiadów fokusowych w zdecydowanie mniejszych grupach, liczących nawet 4-5 uczestników (Barbour, 2011, s. 107-108). Kolejnym ważnym elementem w przygotowaniu projektu badawczego jest wyznaczenie miejsca wywiadu, które może mieć znaczenie dla uczestników, a przez to generowanych przez nich danych. Dowolność oraz różnorodność lokalizacji dla wywiadu fokusowego, przez wielu badaczy uznana za wadę deformującą pozyskany materiał empiryczny, może stanowić cechę wzmacniającą ich potencjał wykorzystany w trakcie analizy. Wybór miejsca w dużej mierze zależy od badacza, który powinien mieć świadomość 
konsekwencji swoich decyzji dla procesu badawczego. Proponowana lokalizacja powinna być dostosowana do tematu dyskusji, predyspozycji uczestników oraz możliwości dojazdowych. Wielu dylematów na poziomie przygotowań przysparza kwestia nagrywania oraz transkrybowania wywiadu. Wybór sprzętu do zapisu zależy od samych badaczy, aczkolwiek dyktafon może nie być wystarczającym źródłem rejestrowania. Kamera umożliwia identyfikację (głosu) uczestników, a nagranie video stanowi w wielu przypadkach dodatkowy materiał analityczny. Z drugiej strony nagrywanie obrazu ma swoje wady, przede wszystkim powoduje stres i dyskomfort uczestników. Pojawiają się trudności dotyczące organizacji logistycznej tj. ustawienie kamer, ujęcie wszystkich uczestników w kadrze, uzyskanie zgody na rejestrację oraz wątpliwa anonimowość badanych. Moderator-badacz wpływa na przebieg oraz dane uzyskane podczas wywiadów fokusowych, podobnie jak w przypadku innych metod jakościowych, dlatego powinien być refleksyjny i świadomy swojej pozycji w prowadzonym badaniu (zob. Barbour, 2011). Ralf Bohnsack (2004, s. 47) wyszczególnia kilka zasad prowadzenia dyskusji grupowej. Przede wszystkim zwraca uwagę na to, że adresatem wytycznych jest grupa, a nie poszczególni członkowie, dlatego moderator nie powinien wywierać wpływu na kolejność wypowiedzi w grupie. Po drugie prowadzący jedynie proponuje tematy, nie narzucając kierunku dyskusji. Poza tym badacz powinien odpowiednio przygotować się do dyskusji, unikając podsuwania uczestnikom gotowych rozwiązań, wymuszania oczekiwanych odpowiedzi lub prezentowania własnych opinii. Badacz powinien być czujny w trakcie wywiadu, dopytując i reagując na wypowiedzi uczestników.

Wszechstronność oraz wielowymiarowość badań fokusowych pozwala na większą dowolność badacza, dając przestrzeń do wykorzystania potencjału i możliwości grup fokusowych. Jednym z głównych walorów wywiadów fokusowych jest możliwość prześledzenia, w jaki sposób w toku dyskusji kształtowane są opinie oraz poglądy indywidualne, a także grupowe. Poza tym pozwalają stworzyć bardziej naturalne i realne warunki sytuacji komunikacyjnej niż inne sposoby zbierania danych (por. Wodak i in. 2009, s. 106-107). Richard Krueger (1988, s. 47) dodatkowo podkreśla wysoką trafność omawianej metody, elastyczność, niskie nakłady finansowe, uzyskanie wyników badań w krótkim czasie oraz orientację społeczną, polegającą na zebraniu materiału empirycznego z realnego życia uczestników. Ponadto zaletą stosowanej metody jest dynamika grupy oraz nieprzewidywalność kierunku dyskusji, dzięki czemu badacz uzyskuje dodatkowy, cenny materiał, o którym wcześniej nie myślał, bądź uważał go za nieistotny. Badacze (por. Krueger, 1988; Lisek-Michalska, 2013; Rushkoff, 2005), opierając się na doświadczeniach, zidentyfikowali kilka wad, trudności, które mogą pojawić się w trakcie procesu badawczego. Ograniczenia tej metody mogą być rezultatem niewłaściwego zachowania badacza, a także okoliczności zupełnie od niego niezależnych. Jako jedno z największych niebezpieczeństw wskazuje się uzyskanie powierzchownych oraz niepogłębionych danych, a także niekorzystny wpływ moderatora na przebieg dynamiki dyskusji. Ponadto uzyskanie zniekształconych danych może być spowodowane narzucającym się moderatorem lub dominującym uczestnikiem. Trudności związane z oswojeniem uczestników z kamerą, dyktafonem, brak anonimowości oraz gwarancji poufności mogą 
zniekształcić wypowiedzi badanych. Na poziomie organizacyjnym należy zadbać o pomieszczenie odpowiadające założeniom zawartym w projekcie badawczym, czas, wyposażenie techniczne, a przede wszystkim o grupę badanych. Wszystkie wyróżnione elementy procedury mogą stanowić trudności, których konsekwencje będą widoczne na etapie samego wywiadu fokusowego. Nieprawidłowości w fazie analizy materiału empirycznego mogą być efektem błędów interpretacyjnych, subiektywizmu analityka, nieumiejętności moderatora, a także prezentowania przez uczestników opinii oraz poglądów o charakterze deklaratywnym. „Najbardziej doniosłe zalety i największe ograniczenia tej metody dotyczą tego samego zjawiska, czyli charakteru interakcji pomiędzy uczestnikami. A te z kolei w znacznym stopniu zależą od moderatora i samej grupy" (Michalska-Lisek, 2013, s. 55). Efekt badań fokusowych, wyróżniających się unikalną specyfiką, zależy w dużej mierze od kompetencji, refleksyjności, doświadczenia metodologicznego oraz wrażliwości etycznej osób projektujących badanie (zob. Michalska-Lisek, 2013).

\section{Etyczny wymiar prowadzenia badań fokusowych}

Problematyka etyki w badaniach naukowych stanowi istotną kwestię dla przedstawicieli wielu dyscyplin naukowych, a szczególnie badaczy społecznych. Towarzyszące badaczowi problemy etyczne dotyczą m.in. celu badań, metody badawczej, doboru uczestników czy kontekstu sytuacyjnego realizowanych badań. Wśród wytycznych regulujących postępowanie etyczne w nauce należy wymienić m.in. Kodeks Etyki Pracownika Naukowego (2017) oraz Międzynarodowy Kodeks Badań Rynku i Opinii, Badań Społecznych i Analityki Danych ICC/ ESOMAR (2016). Dokumenty te regulują ogólne zasady postępowania, które zostały skonkretyzowane w postaci wzorów zachowań obowiązujących przedstawicieli poszczególnych zawodów i określone „etyką zawodową”. Etyki zawodowe to zatem „spisane normy odpowiadające na pytanie, jak - ze względów moralnych - przedstawiciele danego zawodu powinni, a jak nie powinni postępować" (Lazari-Pawłowska, 1969, s. 58). Międzynarodowy Kodeks ESOMAR (2016) odwołuje się do stosowania trzech fundamentalnych zasad obowiązujących podczas prowadzenia badań. Badacz zbierający dane osobowe uczestników winien udzielić badanemu rzetelnych informacji dotyczących zakresu gromadzonych informacji, celu badania oraz odbiorców, którym mają być one udostępnione. Druga z zasad obliguje badacza do zabezpieczenia danych przed nieupoważnionym dostępem oraz nie ujawniania ich bez zgody uczestników. Ostatnia z kluczowych zasad nakazuje badaczowi, by zawsze działał dla dobra badanego i nie podejmował działań, które mogłyby zaszkodzić reputacji lub przyczynić się do jakiegokolwiek uszczerbku badanego.

Warto przeanalizować dylematy etyczne, które towarzyszą badaczowi podczas realizowania badań przy wykorzystaniu wywiadu fokusowego. Procedura prowadzenia wywiadu fokusowego jest bardziej skomplikowana i wymagająca od badacza szczególnej dbałości o kwestie etyczne, porównując tę technikę z innymi czynnościami gromadzenia danych (tj. wywiadem swobodnym lub 
ankietą). Dylematy te odnoszą się zarówno do samych badanych, jak również badacza i jego roli w procesie badawczym. Jedną z najistotniejszych kwestii podczas prowadzenia wywiadu fokusowego jest uzyskanie świadomej zgody badanych na udział w procedurze. Zgodnie z Raportem belmockim „w procesie uzyskiwania świadomej zgody można wyróżnić trzy znaczące elementy: informację, rozumienie i dobrowolność" (Galewicz, 2018, s. 75). Mając na uwadze powyższe wytyczne, obowiązkiem badacza jest przekazanie badanemu wszelkich informacji o badaniu, które mogłyby wpłynąć na podjęcie decyzji o udziale bądź rezygnacji z udziału w badaniu, tj. o warunkach prowadzenia, metodzie, celu, spodziewanych korzyściach oraz niebezpieczeństwach (m.in. emocjach, których badany doświadcza podczas rozmów). Zgoda badanego na udział w wywiadzie grupowym nie powinna ograniczać się jedynie do procesu gromadzenia danych, ale także obejmować aspekty archiwizowania i publikowania danych (Rogowski, 2019). Podczas przekazywania informacji o badaniu badacz powinien upewnić się, że uczestnik właściwie zrozumiał przekazywane treści i jest świadomy ryzyka udziału w badaniu. Szczególne znaczenie podczas wyrażania świadomej zgody na udział w wywiadzie przypisuje się dobrowolności. Niedopuszczalne jest bowiem stosowanie jakichkolwiek form przymusu czy manipulacji w celu uzyskania zgody na udział w badaniu. Ponadto uczestnik ma możliwość odmowy i rezygnacji z udziału w badaniu podczas całego procesu zbierania danych, jak również po jego zakończeniu. Kolejnym istotnym wymogiem podejmowanych badań jest zapewnienie badanym poufności i anonimowości. „Proces anonimizacji jest więc szczególnym wyzwaniem, podczas którego musimy bezustannie sobie przypominać, że badani mogą rozpoznać siebie w naszych analizach, jednak inni nie powinni mieć takiej możliwości" (Mizielińska i in., 2018, s. 82). Kluczową kwestią, o jaką powinien zadbać badacz, jest także właściwe zabezpieczenie notatek, nagrań audiowizualnych i dokumentów, by nie zostały one udostępnione osobom do tego nieupoważnionym.

Wywiad fokusowy jest znacznie bardziej inwazyjny w porównaniu z innymi typami wywiadów. Realizując go, badacz może wywołać zmiany w obszarze poglądów i opinii, które w dłuższej perspektywie mogą przyczynić się do zmian w zakresie samooceny badanych. „Wbrew utrzymywanemu w pozytywistycznym wzorze założeniu o neutralności stosowanych narzędzi badawczych, ingerują one w społeczny i psychiczny świat respondenta (badanego). [...] Stawiając zagadnienie nieco inaczej, chodzi o to, że sytuacja po badaniu nie jest już taka sama jak przed badaniem" (Rostocki, 1992, s. 84). Konsekwencje udziału w wywiadzie fokusowym mogą być bardziej znaczące dla badanych, zarówno w pozytywnym, jak i negatywnym kontekście. Uświadomienie sobie własnych trudności, niepowodzeń, z którymi mierzy się badany, w zestawieniu z kontrastowym doświadczeniem innych uczestników, może wywołać poczucie niespełnienia czy nawet porażki. Badacz staje więc w obliczu trudnego zadania, jak „sprawić, żeby różnice pomiędzy badanymi nie zaciążyły na ich samopoczuciu i nie spowodowały na przykład wycofania się z dyskusji" (Lisek-Michalska, 2013, s. 162). Kolejną kłopotliwą kwestią badań fokusowych jest obawa badanych przed tym, jak zostaną oni odebrani przez pozostałych uczestników badania oraz moderatora. $\mathrm{Na}$ badaczu spoczywa więc trudne zadanie stworzenia pozytywnej atmosfery, 
sprzyjającej dyskusji grupowej i budującej charakter spotkania. Nie może on generować postaw lękowych i wycofania się z dyskusji. Kolejnym zadaniem, jakie stoi przed moderatorem, to właściwy dobór uczestników do badań. Badacz ma bowiem na uwadze dobro badanych oraz obowiązek zapewnienia komfortu podczas wywiadu grupowego. W związku z powyższym ważnym aspektem jest uwzględnienie podobieństwa badanych podczas zapraszania ich do udziału w wywiadzie. Jeszcze inną ważną kwestią w prowadzeniu wywiadu grupowego jest zaangażowanie intelektualne i emocjonalne moderatora oraz wysiłek, jaki towarzyszy mu podczas prowadzonej sesji fokusowej. Często zdarza się, że moderator staje w obliczu poglądów kompletnie sprzecznych z jego własnymi. Nie może sobie jednak pozwolić na komentowanie czy też krytykowanie opinii uczestników, co jest dla niego istotnym dyskomfortem (Lisek-Michalska, 2013).

Podczas prowadzenia wywiadu grupowego badacz mierzy się w wieloma dylematami, które w mniejszym zakresie pojawiają się w badaniach z użyciem innych metod badawczych. Zaniedbanie ważnych pod względem etycznym kwestii może w znaczący sposób przyczynić się, już na etapie planowania procedury badawczej, do pojawienia się błędów o charakterze metodologicznym, odczuwania dyskomfortu przez badanych i badacza, a także obniżyć jakość i wiarygodność pozyskanych danych.

\section{Wywiad fokusowy z udziałem przedstawicieli instytucji pomocowych dla rodzin z problemem alkoholowym}

Zrealizowany przez badaczki wywiad fokusowy z przedstawicielami instytucji pomocowych dla rodzin z problemem alkoholowym stanowił jedną z części szerszego projektu badawczego ${ }^{1}$ dotyczącego znaczenia rodziny w systemie wsparcia społecznego oraz pomocy osobom z problemem alkoholowym. Wstępna analiza oraz interpretacja pozyskanego wcześniej materiału empirycznego (wywiady narracyjne z rodzicami i swobodne z przedstawicielami instytucji) w ramach realizowanego projektu badawczego przyczyniła się do wyłonienia istotnych kategorii, będących punktem wyjścia dla zaprojektowania procedury badawczej wywiadu fokusowego. Przedmiotem badań uczyniono więc doświadczenia przedstawicieli profesji społecznych, na co dzień włączających w swoje działania zawodowe rodziców dorosłych dzieci uzależnionych od alkoholu. Badaczki, celowo zapraszając do wywiadu grupowego przedstawicieli różnych instytucjonalnych form wsparcia, zamierzały stworzyć przestrzeń do dyskusji oraz wymiany doświadczeń badanych, która na etapie analizy umożliwiła zrekonstruowanie strategii pracy

1 W badaniach wykorzystano metodologię teorii ugruntowanej, aby zrekonstruować proces stawania się rodzicem dorosłego dziecka z problemem alkoholowym. Ramy teoretyczne projektu badawczego wyznaczały założenia interakcjonizmu symbolicznego, tym samym perspektywą poznawczą uczyniono paradygmat interpretatywny (Hałas, 2006). Pozyskany materiał empiryczny został poddany analizie w zespole badawczym. Celowo zastosowana triangulacja badaczek oraz danych pochodzących z wywiadów narracyjnych oraz swobodnych umożliwiła pogłębioną analizę. 
z rodzicem dorosłego dziecka z problemem alkoholowym. Wyjątkowo interesujące dla badaczek były prezentowane przez uczestników style pracy, punkty styczne oraz kontrasty wyróżniające przedstawicieli różnych instytucji pomocowych.

Inspiracją do podjętych rozważań były doświadczane przez autorki dylematy oraz trudności o charakterze metodologicznym, etycznym oraz organizacyjnym, które pojawiały się $w$ trakcie przygotowania i realizowania procedury badawczej wywiadu grupowego.

Przyglądając się prezentowanym w literaturze różnym podejściom prowadzenia wywiadu fokusowego, zauważono, że wszystkie były spójne co do porządku jego realizacji (zob. Lisek-Michalska, 2002, 2013; Barbour, 2011). Etap projektowania badania okazał się niezwykle istotny dla samego przebiegu wywiadu fokusowego. Zagwarantowanie uczestnikom komfortowych warunków lokalizacyjnych, bezpiecznej przestrzeni do wymiany doświadczeń, uprzednie zadbanie o wyposażenie techniczne, przygotowanie scenariusza oraz koncepcji badań pozwoliło uniknąć trudności pojawiających się na etapie realizacji. Biorąc pod uwagę fakt, że zaproszeni uczestnicy pochodzili z terenu całej Polski, badaczki świadomie podjęły decyzje o realizacji wywiadu grupowego w dniu konferencji naukowej ${ }^{2}$, w której brała udział znaczna część przedstawicieli instytucji pomocowych.

W pierwszym etapie przygotowania procedury badawczej autorki podjęły próbę opracowania scenariusza wywiadu fokusowego obejmującego trzy główne obszary tematyczne: doświadczenia w pracy $z$ rodzicem dorosłego dziecka z problemem alkoholowym (dylematy, trudności, inicjacja kontaktu, osobisty model pracy, wartości); współpraca przedstawicieli różnych form pomocowych (sieć komunikacyjna, spotkania interdyscyplinarne) oraz proponowane modyfikacje oraz sygnalizowane potrzeby i oczekiwania w stosunku do obecnych rozwiązań systemowych w zakresie wsparcia rodzin z problemem alkoholowym.

Następnie badaczki przystąpiły do rekrutowania, czyli zapraszania potencjalnych uczestników wywiadu fokusowego. Planowały pozyskać po 10 uczestników do dwóch sesji fokusowych, czyli łącznie 20 osób. List zapraszający skierowany został do przedstawicieli praktyki terapeutycznej oraz różnych instytucji, takich jak: sądy, MOPS, GOPS, PCPR, Policja, szpitale. Duży przekrój uczestników był celowym działaniem, zakładającym poznanie różnych perspektyw pracy z rodziną z problemem alkoholowym. Obawiając się odmowy, badaczki świadomie zwiększyły liczbę zaproszonych, wysyłając list do ponad 30 przedstawicieli. W rezultacie udało się pozyskać zgodę od 9 osób, osiągając oczekiwaną różnorodność. Kolejne kroki przygotowań dotyczyły organizacji: sali konferencyjnej z okrągłym stołem, sprzętu rejestrującego (tj. kamera oraz dyktafon) oraz próby technicznej. Należy wspomnieć o triangulacji, którą badaczki zastosowały celowo dla osiągnięcia szerszej perspektywy analitycznej. Podczas etapu projektowania procedury badawczej oraz realizacji wywiadu grupowego były zaangażowanego dwie badaczki, natomiast do ostatniego etapu analizy został włączony cały zespół

2 Wywiad fokusowy odbył się podczas Ogólnopolskiej Konferencji Naukowej „Rodzina w systemie wsparcia społecznego i pomocy osobom z problemem alkoholowym", pod patronatem Rektora Uniwersytetu Łódzkiego - prof. dr hab. Antoniego Różalskiego. Konferencja odbyła się w Łodzi 23.04.2019 r. 
realizujący projekt badawczy „Rodzina w systemie wsparcia społecznego i pomocy osobom z problemem alkoholowym. Badania biograficzne z udziałem rodziców (dorosłych) dzieci uzależnionych od alkoholu”.

\section{Refleksje badaczek}

Poddając refleksji zrealizowane badania fokusowe z udziałem profesjonalistów na co dzień pracujących z rodzinami z problemem alkoholowym, wyłoniłyśmy dwa typy trudności (tj. zewnętrzne oraz wewnętrzne), które pojawiły się podczas projektowania oraz realizacji procedury badawczej, a także analizy pozyskanego materiału empirycznego. Pierwszy typ doświadczanych trudności jest w wielu przypadkach niezależny od badaczy oraz nieprzewidywalny, ulokowany w czynnikach zewnętrznych. Drugi typ problemów, które pojawiły się w trakcie realizacji wywiadu fokusowego, pochodzą z dylematów (wewnętrznych) towarzyszących autorkom. Warto zaznaczyć, że doświadczane trudności nie świadczą o niekompetencji badaczek, wręcz przeciwnie - świadomość doświadczanych przeszkód umożliwia szybką oraz skuteczną reakcję na pojawiające się podczas badania problemy. Trudności wewnętrzne mają specyficzny charakter, ponieważ są efektem interakcji z uczestnikami badania.

Efektem doświadczanych dylematów były reakcje na sposoby radzenia sobie badaczek z przeszkodami. Przede wszystkim zdecydowały się na moderowanie wywiadu w zespole, który składał się z dwóch badaczek. O wyborze dwuosobowego zespołu badawczego pisze Burman, Butchelor oraz Brown (zob. 2001), wskazując na zalety takiego rozwiązania. Przede wszystkim można wykorzystać potencjał oraz kompetencje członków zespołu, podzielić się obowiązkami oraz wznieść dyskusje na wyższy poziom, dzięki temu, że badaczki wzajemnie się wspierają i uzupełniają. Postępując zgodnie z wymogami etyki, badaczki starały się pozyskać świadomą zgodę potencjalnych uczestników na udział w badaniu. Mając to na uwadze, rzetelnie przedstawiły cel badania, zaprezentowały metodę oraz przedstawiły korzyści płynące z zaangażowania w badanie. Poinformowały także o sposobie rejestrowania wywiadu w postaci nagrania audiowizualnego oraz możliwości sporządzania przez nie notatek. Szczególnie informacja dotycząca nagrywania wywiadu przy użyciu dyktafonu oraz kamery wzbudziła wśród badanych niechęć do udziału w dyskusji i w konsekwencji mogła przyczynić się do odmowy części badanych. Profesjonaliści komunikowali również obawy przed ujawnieniem własnych poglądów i opinii w kwestii pomocy rodzinom z problemem alkoholowym, a także niechęć do konfrontacji z doświadczeniem innych uczestników badania. Jednym z dylematów odczuwanych przez badaczki było wstępne założenie realizacji dwóch wywiadów w dniu konferencji. Lisek-Michalska (2013, s. 169) uważa bowiem, że „dla moderatora zaangażowanego w projekt prowadzenie sesji fokusowej jest bardzo intensywnym wysiłkiem intelektualnym i psychicznym". Badaczki zweryfikowały więc (jeszcze na etapie przygotowań) powyższy plan, zakładając możliwość zbyt dużego obciążenia emocjonalnego dla nich samych. W wyniku refleksji oraz odmowy części profesjonalistów udziału w badaniu 
zrealizowały jeden wywiad focusowy w dniu konferencji. Finalnie pozyskano więc do badań 9 uczestników, którzy świadomie wyrazili chęć udziału w wywiadzie, co potwierdzili, wyrażając pisemną zgodę na udział w badaniu, nagrywanie i transkrypcję. Realizatorki badań założyły, że atmosfera konferencji wzmocni wśród badanych poczucie powagi poruszanych kwestii oraz będzie dla nich czynnikiem potwierdzającym ich umiejętności i kompetencje jako profesjonalistów w pracy z rodzinami z problemem alkoholowym. Uwzględniając założenie badaczek dotyczące pozyskania danych od ekspertów z całej Polski oraz stwarzając badanym dogodne warunki, badaczki zastosowały zabieg jednorazowego angażowania uczestników. Kolejną obawą, z którą musiały zmierzyć się badaczki była relacja badacz - badany. Moderatorki wywiadu fokusowego podczas konferencji występowały w podwójnej roli naukowca i realizatora badań, co mogło przekładać się na stworzenie określonej atmosfery spotkania. Ostatecznie badani sygnalizowali pozytywny odbiór chęci współpracy środowiska naukowego z ekspertami w celu rozwiązania ważnych problemów społecznych.

Jak wspomniano wcześniej, szczególną trudnością, przed którą stanęły moderatorki, już podczas realizacji wywiadu w dniu konferencji, było poradzenie sobie ze świadomością badanych, że spotkanie jest rejestrowane w wersji audiowizualnej. Zupełnie spontanicznym, ale skutecznym rozwiązaniem okazało się umieszczenie kamery w szczycie pomieszczenia, gdzie urządzenie było wręcz niewidoczne. Jeżeli chodzi o dyktafon, który leżał na stole, sprawdziło się przykrycie go pojedynczą białą kartką. Dźwięk nie stracił na jakości, a badani, nie widząc urządzenia, zapomnieli, że spotkanie jest rejestrowane. Analizując wybraną literaturę przedmiotu, zauważa się trwającą debatę na temat nagrywania oraz transkrybowania dyskusji grupowej za pomocą sprzętu elektronicznego. O ile niezbędny okazuje się dyktafon, o tyle użycie kamery jest wątpliwe i czasami może zakłócić badanie. Nagrania video „mogą zwiększyć dyskomfort lub samoświadomość uczestników, dochodzą do tego trudności z zachowaniem anonimowości, wyzwania logistyczne związane z ustawieniem kamer, ograniczona zdolność uchwycenia wszystkich uczestników na taśmie oraz limit osób, których dyskusję można zarejestrować" (Borbour, 2011, s. 130-131). Opisywane powyżej dylematy towarzyszyły badaczkom podczas projektowania badania, aczkolwiek podjęły decyzję o włączeniu kamery do sprzętu rejestrującego z obawy przed tym, że nagranie audio może być niewystarczające do zidentyfikowania uczestników, co było niezbędne dla analizy wygenerowanych danych. Przygotowując się do realizacji wywiadu, badaczki miały również świadomość podejmowania w dyskusji grupowej drażliwego tematu, który mógłby wiązać się z ujawnieniem sposobów pracy ekspertów z określonej instytucji pomocowej, a z drugiej strony zdradzać pewne wady systemu, instytucji czy samych badanych. Konsekwencją tego mogłaby być niechęć badanych do podejmowania dyskusji i otwartego wyrażania własnych poglądów. Obawy badaczek dotyczyły także możliwości wystąpienia z jednej strony konfliktów, a z drugiej prezentowania zbyt dużej zgody w poglądach uczestników wywiadu. Zakładając możliwość wystąpienia takiej sytuacji, moderatorki rzetelnie przygotowały awaryjny scenariusz wywiadu, uwzględniając w nim zarówno kwestie aktywizujące dyskusję badanych oraz podkreślające spójność podejmowanych przez profesjonalistów strategii w pracy z rodzinami osób z problemem 
alkoholowym. Trudności dotyczące drażliwego tematu (problemu alkoholowego) spowodowały, że na początku uczestnicy przyjęli bardzo ostrożną postawę wobec pytań (niepożądana „rundka szkolna”, nie było rozmowy, tylko odpowiedzi), które zadawały moderatorki. Pomimo zaprojektowanego scenariusza oraz obszarów tematycznych badaczki musiały reagować na bieżąco, podążając za rozmową badanych. Istotnym (przełomowym) punktem okazało się odstąpienie autorek od zaplanowanego szkicu i zadanie pytania o „ICH” perspektywę pracy z rodzicami dorosłych dzieci z problemem alkoholowym. Odwołanie się do osobistych doświadczeń zawodowych spowodowało, że zaczęły się wyłaniać podobieństwa i kontrasty wyróżniające przedstawicieli różnych instytucji pomocowych. Zastosowanie takiego zabiegu było początkiem dyskusji, która przebiegała w bezpiecznej i przyjemnej atmosferze. Kolejnym obszarem generującym trudności okazała się kontrola przebiegu dyskusji, która w momencie osiągnięcia zupełnej swobody przez uczestników zaczęła przypominać superwizję. Ten moment był niezwykle trudny dla badaczek, ponieważ towarzyszyło im poczucie degradacji i dyskwalifikacji. Jedynym sposobem, który wtedy wydawał się trafny i racjonalny, było uprzejme upominanie i przypominanie o celu spotkania oraz głównym temacie dyskusji. W rezultacie zrealizowane wywiady fokusowe dostarczyły bogaty materiał empiryczny, otwierając nowe przestrzenie analityczne.

\section{Podsumowanie}

Zrealizowane badanie fokusowe z przedstawicielami instytucji pomocowych dla rodzin z problemem alkoholowym stanowiły jedną z części szerszego projektu badawczego dotyczącego znaczenia rodziny w systemie wsparcia społecznego oraz pomocy osobom z problemem alkoholowym. Wstępna analiza oraz interpretacja pozyskanego wcześniej materiału empirycznego (wywiady narracyjne z rodzicami i swobodne z przedstawicielami instytucji) przyczyniła się do zaprojektowania procedury badawczej wywiadu fokusowego, do którego zaproszono profesjonalistów, przedstawicieli instytucji pomocowych, takich jak: MOPS, GOPS, Policja, szpitale, gabinety terapeutyczne, sąd, PCPR.

Celem powyższych rozważań była refleksja nad dylematami o charakterze etyczno-metodologicznym, których doświadczyły badaczki w trakcie realizacji badań fokusowych, a także zaprezentowanie sposobów radzenia sobie z pojawiającymi się trudnościami. Odwołując się do założeń teoretycznych, badacze decydujący się na wybór badań fokusowych, powinni mieć świadomość potencjalnych zagrożeń oraz dylematów towarzyszących realizatorom. Poddając refleksji zrealizowane badania z udziałem profesjonalistów na co dzień pracujących z rodzinami z problemem alkoholowym, wyłoniono dwa typy trudności (tj. zewnętrzne oraz wewnętrzne), które pojawiły się podczas projektowania oraz realizacji procedury badawczej. Pierwszy typ doświadczanych trudności jest w wielu przypadkach niezależny od badaczy oraz nieprzewidywalny, ulokowany w czynnikach zewnętrznych (niechęć uczestników, odmowy, redukcja grupy, prawno-etyczne aspekty związane ze zgodą na udział w badaniu). Drugi typ problemów, które 
pojawiły się $\mathrm{w}$ trakcie realizacji wywiadu fokusowego, pochodzą z dylematów (wewnętrznych) towarzyszących autorkom (trudności, które często pojawiają się w trakcie wywiadu grupowego, tak samo nieprzewidywalne, ale będące efektem interakcji z uczestnikami, jak: oswojenie z nagrywaniem spotkania, kontrola przebiegu, trafne pytanie inicjujące). Uzasadnieniem dla wyboru wywiadu grupowego było stworzenie (osiągnięcie) atmosfery sprzyjającej wymianie doświadczeń przedstawicieli różnych instytucji. Pomimo doświadczanych trudności metoda wywiadu grupowego okazała się trafnym wyborem, ponieważ umożliwiła profesjonalistom podjęcie swobodnej dyskusji, podczas której ujawniły się wcześniej nieanalizowane przestrzenie problemowe, istotne dla codziennej pracy z rodzinami z problemem alkoholowym. Pomimo opracowanego wcześniej scenariusza zaangażowanie uczestników spowodowało, że dyskusja biegła swoim, niewymuszonym tempem, a pytania zawarte w scenariuszu stanowiły jedynie obszary tematyczne, które służyły badaczkom bardziej jako „narzędzie pomocnicze” porządkujące przebieg badania.

\section{Bibliografia}

Babbie E. (2013), Podstawy badań społecznych, Wydawnictwo Naukowe PWN, Warszawa.

Barbour R. (2011), Badania fokusowe, Wydawnictwo Naukowe PWN, Warszawa.

Bohnsack R. (2004), Dyskusja grupowa - teoria i praktyka rekonstrukcji kolektywnych wzorów orientacji, [w:] S. Krzychała (red.), Społeczne przestrzenie doświadczenia. Metoda interpretacji dokumentarnej, Wydawnictwo Naukowe Dolnośląskiej Szkoły Wyższej Edukacji TWP we Wrocławiu, Wrocław, s. 36-48.

Drapikowska B., Palczewska M. (2013), Zogniskowany wywiad grupowy oraz techniki projekcyjne jako przykłady jakościowych empirycznych metod badawczych stosowanych w naukach społecznych, „Obronność - Zeszyty Naukowe Wydziału Zarządzania i Dowodzenia Akademii Obrony Narodowej" 3(7), s. 71-86.

Galewicz W. (2018), Raport belmoncki: Etyczne zasady i wytyczne dotyczące badań z udziałem ludzi, „Narodowa Komisja Ochrony Osób Uczestniczących w Badaniach Biomedycznych i Behawioralnych (USA)", https://www.nil.org.pl/_data/assets/pdf_file/0007/81394/raport_belmoncki_galewicz.pdf (data dostępu: 14.06.2019), s. 69-82.

Hałas E. (1994), Obywatelska socjologia szkoły chicagowskiej. Charles H. Cooley, George H. Mead, Herbert Blumer, Redakcja Wydawnictw Katolickiego Uniwersytetu Lubelskiego, Lublin.

Hałas E. (2016), Refleksyjny podmiot $w$ świecie społecznym. O paradygmacie i założeniach socjologii interpretacyjnej, „Roczniki Nauk Społecznych” 44(4), s. 35-50.

Kidd P., Parshall M. (2000), Getting the focus and the group enhancing analytical rigor in focus group research, „Qualitative Health Research” 19(3), s. 293-308.

Kodeks etyki pracownika naukowego (2017), PAN, Warszawa https:/instytucja.pan.pl/images/2016/ komisja_etyki/Kodeks_etyki_pracownika_naukowego_-_wydanie_II_-_2016_r.pdf (data dostępu: 14.06.2019).

Konecki K. (2000), Studia z metodologii badań jakościowych. Teoria ugruntowana, Wydawnictwo Naukowe PWN, Warszawa.

Krueger R.A. (1988), Focus Groups, Sage, Newbury Park, Ca.

Lazari-Pawłowska I. (1969), Etyka zawodowa, „Etyka” 4, s. 58-90.

Lisek-Michalska J. (2002), Focus - sztuka czy metoda, „Ruch Prawniczy, Ekonomiczny i Socjologiczny" 1 , s. 311-326.

Lisek-Michalska J. (2013), Badania fokusowe. Problemy metodologiczne i etyczne, Wydawnictwo Uniwersytetu Łódzkiego, Łódź. 
Litosseliti L. (2005), Using focus groups in research, MPG Books Ltd., Bodmin, Cornwall.

Międzynarodowy Kodeks Badań Rynku i Opinii, Badań Społecznych i Analityki Danych ICC/ESOMAR (2016), http://www.ofbor.pl/public/File/Miedzynarodowy_Kodeks_Badan_Rynku_i_Badan_Spolecznych.pdf (data dostępu: 14.06.2019).

Mizielińska J. i in. (2018), Dylematy etyczne w badaniu pary intymnej. Doświadczenia z pracy badawczej, „Studia Socjologiczne” 3(230), s. 71-100.

Morgan D. (1997), Focus groups as qualitative research, Sage, Newbury Park, Ca.

Murphy B. (1992), Focus groups in health research, „Health Promotion Journal of Australia” 2, s. 37-40.

Piotrowski A. (1998), Ład interakcji: studia z socjologii interpretatywnej, Wydawnictwo Uniwersytetu Łódzkiego, Łódź.

Rogowski Ł. (2019), Etyczne dylematy badań biograficznych z wykorzystaniem fotografii: perspektywa badaczy i badanych, „Przegląd Socjologii Jakościowej” XV(2), s. 58-75.

Rostocki W.A. (1992), Bezradny respondent. Trudność pytań w wywiadzie kwestionariuszowym, Instytut Socjologii Uniwersytetu Łódzkiego, Łódź.

Rushkoff D. (2005), Get back in the box: innovation from the inside out, Collins, New York.

Wodak R. i in. (2009), The discursive construction of national identity, Edinburgh University Press, Edinburgh.

\section{Abstract}

The aim of the article is to reflect on the ethical and methodological dilemmas experienced by researchers during planning and implementation of focus studies with representatives of the institutional support system for families with alcohol problems. The first part includes the main theoretical assumptions concerning the implementation of focus studies, pointing to the variety of approaches, doubts and dilemmas resulting, among others, from the status of the methodological examination of the focus group, elements of the research procedure, ethics, selection of participants, the analysis of the collected empirical material, the role of the moderator, the selection of space and the method of registration of the study. In the subsequent methodological part, the researchers presented the detailed course of the research procedure, which provides an introduction for the third and final analytical part, in which the authors present dilemmas, as well as ways of dealing with methodological constraints, simultaneously indicating the potential and opportunities related to focus tests. The focus interview carried out by the researchers with representatives of support institutions for families with alcohol problems was part of a wider research project.

The article is a result of a project titled "Family in the system of social support and help for people with alcohol problems. Biographical research with the participation of parents of adult children addicted to alcohol" carried out as the following task: "Supporting scientific research in the area of problems resulting from the use of alcohol". The project conducted by the research team from the Special Pedagogy Laboratory at the Faculty of Education Sciences is financed by the Gambling Problem Solving Fund, as part of the National Health Program for the years 2016-2020.

Keywords: qualitative research, focus interview, ethical dilemmas, methodological problems, social research 